Meenakshi Ahluwalia

A405 Purvasha Apartments

Anand Lok Group Housing Society

Mayur Vihar, Phase I

Delhi-91

India

email: walia@giasd101.vsnl.net.in

fax: 91116845135

Stream: Governance - Water/Watersheds/Irrigation

Discipline: Interdisciplinary

\title{
Representing Communities: the Case of a Community-Based Watershed Management Project in Rajasthan, India
}

\section{Introduction}

In the Indian development policy context there is increasing concern about why community-based natural resource management projects fail to achieve their expected levels of equity or sustainability (Saint, 1995; Kerr, 1996). Such community-based approaches are themselves a departure from earlier policies which tended to be based solely on state priorities, treating natural resource management as a technical and administrative issue, rather than a socio-economic and political one (Pretty and Shah, 1996), and focusing on large-scale projects such as large dams, reservoirs and canal systems (CSE, 1985). The high social and environmental costs of such schemes, now well-documented, have been an important stimulus in a shift evident since the 1980s towards small-scale community-based projects.

In this context, donors, governmental and non-governmental organisations (NGOs) are currently investing heavily in participatory watershed development. Widely cited project examples include the Sukhmajri project (Chopra, 1990) and the Relagaon Sindhi Project (Deshpande and Reddy, 1991). NWDPRA is a well-funded endeavour undertaken by central and the state governments with the objective of involving people in project planning, implementation and maintenance, over 99 districts in 16 states. World Bank-funded integrated watershed development projects have also been launched, covering 94 watersheds.

Emerging critiques of such projects highlight how, for instance, farmers are used as labourers for construction or the interests of the weaker sections of society are overlooked so that they bear the labour burden of the projects for little benefit (Sharma, 1995). Some schemes have floundered in the face of local resource conflicts. In other cases, farmers accept otherwise unsuitable programmes because they offer a short-term source of income and access to subsidies, but 
resource management efforts are not sustained beyond the departure of the implementing agency (Sanghi, 1987; Pretty and Shah, 1996). Many of these problems can be traced to the misleading assumptions about 'community' and 'participation' informing these approaches. Certain commentators are now urging the need for greater attention to local ecological specificity, social organisation and institutions in natural resource management in the Indian context (e.g. Mosse, 1997).

This paper focuses on a community-based watershed project in Rajasthan to provide a better understanding of how social, institutional and ecological dynamics affect practical efforts to achieve community-based sustainable development. The paper applies the tools of environmental entitlements analysis in a project evaluation mode to explore how people's different endowments and entitlements to natural resources, as influenced by institutions, affect their experience of watershed development interventions. The paper also considers whether social actors' differential abilities to overcome the transaction costs that they face make it viable for them to invest in institutions and environmental management in the ways expected by the project.

\section{Nayakheda Watershed Development Project}

The Nayakheda watershed project covers around 200 hectares and falls on the border of Rajsambandh and Udaipur districts of Rajasthan (Figure 1). The terrain of the region is hilly and undulating, and the climate sub-humid, with a mean annual rainfall of $645 \mathrm{~mm}$ falling largely during the June-September monsoon. There is considerable inter-annual variation in rainfall, although little evidence to support the popular belief that rainfall in Rajasthan is declining.

Figure 1 Location of the study area within Udaipur district, Rajasthan, India

The project has been facilitated by Seva Mandir, a non-governmental organisation based in Udaipur. Seva Mandir began its activities in Nayakheda in 1979 with adult literacy and informal education, followed in the mid-1980s with food-for-work relief activities in response to drought, and from 1986, an emphasis on leadership training and organisational and group formation skills. Since 1993 Seva Mandir has been focusing on soil and moisture treatments on private and common land. Seva Mandir considers Nayakheda watershed project as one of its best. The indicators of this success are not limited to the sphere of natural resource management; Seva Mandir takes pride in local social solidarity, claiming that due to their efforts the community, which was once divided along caste and class lines, is now able to unite, partake of food and water from the same pot and find joint solutions to common problems.

Nevertheless, this 'community' is highly heterogeneous. Administratively the project covers two districts, three villages and seven hamlets. Socially and economically the community is highly differentiated, comprising a conglomerate of two tribes, five castes and several class groups, dependent on diverse sources of livelihood. Such heterogeneity is typical of the Indian context. For many, this would not be a 'community' at all. The Nayakheda case study thus provides an interesting opportunity to explore how social groups of such diverse interests are able to form a 
functional community around natural resource management as the NGO assumes; or indeed, what might be concealed by this representation.

In the following sections, three examples of Seva Mandir's interventions and an assessment of their impact on different social actors within the 'community', using the environmental entitlements framework are presented (see Figures 2-4).

\section{Investment in capabilities by Seva Mandir}

Seva Mandir started work in Nyakheda not by investing in natural resources but by investing more generally in capability enhancement. Here, I ask how far this project case provides a confirmatory illustration of the idea that investments in social and human capital can impact positively on natural resource management (Figure 2).

Figure 2 Environmental entitlements analysis: investment in capabilities by Seva Mandir

Seva Mandir entered Nayakheda with an adult education program. As NGO staff became familiar with the village and its dynamics it realised that though the feudal or mafidari system had been officially abolished in 1955, the son-in-law of the ex-mafidar continued to exploit the villagers. One of the factors underlying his unrestrained power was that the soap stone mines he owned were the only source of cash income available locally. Seva Mandir broadened its objectives to overcome this problem. On the one hand it ensured that alternative sources of employment were generated within the project while on the other hand they made group formation, leadership training and organisational skill training a focal point of their agenda. Through an increase in self confidence and political awareness generated by these programmes it was hoped that the claimsmaking capacity of the community would be enhanced.

Seva Mandir's efforts do indeed seem to have enhanced the community's capacity to make claims on public authorities, engage in political bargaining and negotiate and mediate conflicts. For instance, Shivlal Parmar, a member of the gameti Scheduled Tribe who has been particularly closely involved with Seva Mandir's activities, was elected to the village council in 1994, winning the election in a struggle with the village's mine owner, a corrupt bureaucracy and an equally corrupt party system which did what it could to stop independent candidates (Frazer, 1996). What is important here is not that Shivlal is the first tribal village headman in the area; thanks to the Indian Government's affirmative action policy a tribal would have become a village headman in any case. The important point is that Shivlal was elected against another candidate who was supported by the ex-feudal lord, who had used both threat and money to woo the voters to no avail. Through their victory over the local elite the people did not only find that they could cooperate over caste divisions, but also realised the strength of their unity.

An excellent illustration of the instrumental consequences of such investment in capabilities for natural resource management - and community endowments - can be seen in the case of a contested plot of land in the village. The powerful Rajput mine-owner was pressurising Shivlal to 
allow him to set up a stone thresher in the middle of the tribal hamlet. The mine-owner tried to impress upon Shivlal that this would benefit the tribal community by placing a source of employment at their doorstep. But Shivlal was able to see through his ploy, understanding that the mine-owner was driven by personal monetary gain, and to confront him, asking "will the tribal always run to the areas which are not wanted by the upper castes. How do you expect we will live in midst of the dust? Will you people never let us live in peace?" Failing to fool Shivlal, the mine-owner tried to bribe him and threatened to take his life. Fortunately Shivlal did not give in to his pressure and instead allotted the land for housing, as preferred by the villagers.

This incident makes for more than an interesting anecdote because of the institutional changes it reveals. That the village headman could stand up for the rights of the people of his hamlet suggests that there has been a change in local power politics, such that unity - at least in this context - now cuts across caste and class. While the government's affirmative action policy played a key role in bringing about this change, the efforts of Seva Mandir in the development of human and social capital in the village cannot be overemphasised. That the villagers are now capable of asserting their rights and fighting corruption also reflects the adult education activities of the NGO. Seva Mandir had been instrumental in reducing villager's dependence on exploitation-based livelihoods and an exploitative traditional patron. In addition, Seva Mandir had invested much time and energy in enhancing group cohesion, and had encouraged the people to choose their own representative in the local village council. Therefore it would be fair to say that this scenario was made possible by the sustained efforts of a new institution, the NGO Seva Mandir.

In this case, then, a 'community' did act across caste, class and gender divides towards a collective good. The concept of community - and representations of community - are clearly important. Nevertheless, these representations were invoked in a particular political and economic context. In other contexts, the people of Nayakheda appear much less united, and what is relevant for one group of social actors is irrelevant or detrimental for others. A perfect case in point is the socially differentiated impact of soil and moisture conservation measures undertaken on private and common land by Seva Mandir.

\section{Soil and moisture conservation on private lands}

Nayakheda, like most of the Aravalli Hills, has witnessed significant deforestation and vegetation denudation during the last two decades. Satellite data clearly indicate that between 1975 and 1996 there has been a significant decline in forest cover within the project area: from 301 ha in 1975 to 179 ha in 1996 . This information is corroborated by oral testimonies from the area's inhabitants.

While dominant policy narratives about the area reproduce the idea of population-induced deforestation, principally by poor tribal people to meet their subsistence needs, life histories and ecological histories with various informants revealed a different set of causes. The most important was the delay in the enactment and ineffective implementation of the land reform of 1955, which encouraged mafidars to exploit timber and other resources on land which they anticipated would be seized by the government (Singh, 1964). Although it was tribal people who carried out these destructive practices, they did so in response to the incentives offered by the mafidars. The 
products were used more for local industry than for tribals' subsistence. Moreover, the reform of 1955 disregarded previous institutions managing natural resources, contributing to the decline of existing common property management institutions without replacing them. Many commons were, as a result, privatised, encroached upon or degraded (Jodha, 1989).

In 1992, Seva Mandir intervened with a set of traditional soil and moisture conservation measures aimed at regenerating biomass. These included a subsidy on the construction of stone-walled terraces (medbundi), gully plugs and boundary walls, and digging pits for rainwater harvesting and tree plantation. Preliminary evidence confirms that Seva Mandir is succeeding in attaining its intended targets of increases in biomass and soil moisture and in recharging groundwater. During transect walks people would point to their fields saying, "this year I had to irrigate my fields only twice, normally I would irrigate it five times. This has been possible because soil has retained moisture due to checkdams". Many people are now able to harvest three crops in the season. Growing vegetables is the favourite third crop, although a few farmers have invested in more water-hungry crops such as sugar cane. That there has also been a rise in the water table is suggested by villagers who claimed, for example, that "thirteen wells which used to dry up earlier in the dry season had water this year". In a survey of perceived changes in well-depth among 30 households, 50 per cent of households reported that there had been no change in the water table, 47 per cent reported a rise in the water table and the remaining 3 reported a fall.

However, the benefits of the project have not reached the community evenly. First, in principle anyone having private arable land and water rights would have access to a 50 per cent subsidy to undertake soil and moisture treatments on their private lands. But in practice only those who could reach agreement with the owners of consecutive plots could gain access to Seva Mandir subsidies, since Seva Mandir maintains a policy of treating only the plots of 3-5 or 8-10 households who agreed to construct, repair and maintain the measures in cooperation.

Second, people's gains were dependent on their initial endowments. Those who derived a greater share of their livelihood from farming, had larger land holdings in valley bottom areas and had access to water for irrigation stood to gain most. The institutions mediating access to land in the area are inheritance, caste and claims grounded in local settlement history. However, powerful individuals are able to encroach on other's or common land by bribery or through tacit agreements with the local revenue collector. Rights to water from wells is also subject to inheritance. Most wells are privately owned, and rights accrue to the descendants of those who made contributions of labour or cash for the original construction of the well (Figure 3).

Figure 3 . Environmental entitlements analysis: soil and moisture conservation on private lands

To sum up, preliminary evidence confirms that Seva Mandir is succeeding in attaining its intended target of recharging the groundwater. However, the initial distribution of endowments in terms of location of wells and land holdings in relation to micro topography affects the social distribution of gains from soil and moisture conservation. 


\section{The socially-differentiated impact of enclosure of commons}

In addition to interventions on private land, Seva Mandir has attempted to arrest degradation of the commons. With local consent, the NGO has enclosed major areas of village common land, undertaken soil and moisture conservation measures and planted grass and trees on treated land. In principle all village members share equal access rights to the commons, but it is necessary first to assess the extent to which such endowments are translated into effective entitlements. It is therefore important to ask: in practice does everyone have equal access to products from the commons, and in this context, what has been the socially-differentiated impact of Seva Mandir's activities?

Since the abolition of the feudal or zamindari system in 1955, state land laws and government policy have recognised all village members as having rights of access to village commons; rights acknowledged informally in the village. But these endowments are not always translated into entitlements in practice because certain people have been able to use their social, political, or economic positions to forge tacit agreements with the government land registrar (patwari), enabling them to encroach on common land. One of the aims of the commons enclosure policy of Seva Mandir was to enable community members to translate communal rights into practice.

Environmental entitlements, in this case, are fodder, fuelwood, fruit, timber and stone, or income derived from the sale of any of these (Figure 4). In the pre-Seva Mandir period it was assumed that, since everyone had equal access to the commons, norms of fairness would automatically operate and everyone would enjoy these benefits equally. However, by virtue of caste-based occupational specialisation (e.g. Gairis are principally sheep rearing and Rebaris are principally camel rearing groups, making heavy use of commons for grazing) and class (e.g. a rich Gairi has more sheep and is more powerful than a poor Gairi), or family size, certain social actors regularly derived greater entitlements than others. Seva Mandir sought to rectify this 'messiness' by asking the community to elect their representatives as committee members. The committee members were given the responsibility of ensuring equity in commons use. For instance, new rules stipulate that only one member per household can enter the commons on a specified date to collect fodder.

Figure 4 Environmental entitlements analysis: impacts of the closure of the commons

In spite of these measures taken by Seva Mandir, the entitlements and capabilities of women, however, remained largely unchanged. For instance, although women were largely responsible for collecting wild fruits from the commons, owing to their seclusion from the market, it was men who took responsibility for selling them and thus for control over the income generated. This reinforced women's inferior position and increased their workload.

Likewise, certain livestock rearers have faced greater transaction costs than others in complying to the norms revolving around regulated use. They have been forced to travel greater distances to get fodder for their livestock or to buy grazing rights. In contrast, large landowners, because of their alternative endowment bundles of private pasture land, have been able to cope with the 
enclosure relatively easily. Moreover, livestock rearers are not compensated by the current land conservation subsidies, whereas private arable land-holders benefit both from short run subsidies that allow them to treat their land, and the expected longer run benefits of the treatment themselves.

An unintentional impact of the enclosure of the commons has been a change in the composition of livestock. This has knock on effects on the value of different kinds of livestock and the livelihood of the community in the long run. Due to scarcity of fodder, people in the area are replacing camels and sheep with goats. According to a village elder, whereas "once upon a time there were hundreds of camels in this area, now we cannot find even five camels". Gairis and other livestock rearers are increasingly migrating out of the village or looking for cash employment, as their traditional livelihood is no longer viable. This has had effects on the value of different kinds of livestock and the livelihood of the community in the long run.

In sum, although in principal everyone is expected to gain equally from the watershed programme, certain social actors - due to their initial endowments and the operation of prevalent local institutions - have actually lost from it, whether in terms of increased workload, loss of income, additional expenses or forced changes in livelihood.

\section{Stakeholders, Conflict and Institutions}

These three cases illustrate that the outcome of community based projects cannot be dissociated from local power politics. In this section, I reflect on the implications of social difference, conflict and their institutional mediation for strategies in community-based sustainable development, again through the example of Seva Mandir in Nyakheda.

Given the problems in assuming a homogeneous community, identifying the various sociallydifferentiated stakeholders, analysing the stakes, priorities, benefits and losses which they might face, and negotiating a mutually beneficial agreement would seem to be a precondition for success. Identification of clear groups of social actors, however, is fraught with problems. Social identities are multiple and overlapping so that, for instance, while 'women' can be treated as a single social group in certain resource contexts, in others, cross-cutting differences such as marital or caste status shape their options in critical ways. For example, a Rajput (high caste) widow in the case study area felt extremely insecure as caste-based seclusion norms prohibited her from undertaking any form of employment, leaving her dependent on the charity of her relatives. Neither the wage labour nor the 'women's development' activities offered by the project brought any benefit for her. By contrast, a Bhil (tribal) widow undertook wage employment within the project and also requested from the women's development personnel of Seva Mandir that she be given a post as a para-worker. The presence of Seva Mandir and the project offered various opportunities for her.

But having established that it is important to recognise complexity, it should be added that if each combination of multiple social attributes is treated as a single type of stakeholder, the latter become innumerable. A balance in such analysis must thus be struck between generality and complexity according to the needs of each local situation and its power politics. In the case of 
Nyakheda, a particular set of stakeholders, and the different alliances each forged with the project, seemed to affect the project outcomes. These groups were: herder-farmers; farmer-herders; small farmer wage earners; Rajput women; scheduled caste and schedule tribe women; village committee members and Seva Mandir para-workers, and the mineowner-landlord. All the other stakeholders were united in their conflict with the mineowner-landlord, illustrating the force of hatred for a common enemy in building community solidarity. Equally, the group-formation activities of Seva Mandir, and particularly the perseverance and continuous presence of a dedicated Seva Mandir zonal worker, provided a context in which people united against this landowner, thereafter treating the success of Seva Mandir's endeavours as a symbol of their success in this struggle.

However, that such a community could be mobilised to take support from Seva Mandir and other outside organisations to fight local politics does not imply that there is a community around natural resource management. The latter is, rather, infused with conflict both among local social actors, and between them and Seva Mandir's project intentions; conflicts which can generate resistances and compromise project objectives. These conflicts are grounded in the fact that people derive their livelihoods from various sources and are, as a consequence, dependent on different types of natural resource. In the case of Nayakheda, there is increasing unrest amongst those households who are mainly dependent on livestock rearing; they have good reason to challenge the norms regarding the enclosure of commons, just as large landowners have good reasons to support it.

Ignoring such conflicts risks livestock owners sabotaging the project. While the problem in Nayakheda has not yet reached such critical dimensions, several Gairis pointed out in a group meeting that:

We were lured into enclosing the commons because Seva Mandir was investing in our lands. Moreover, it gave us wages to see us through a rough time. But now when we have to sell our animals we realise the full import of our deeds. There is no grazing land and the grass from the enclosures was not enough. Moreover, it is robbing us Gairis of our original occupation. If this sort of situation continues then we shall be forced to destroy the enclosures.

The lack of open protest to date partly reflects the small numbers, and lack of organisation, of such resisting groups, as well as the fact that project activities are still in progress. But this group is highly likely to protest against project rules unless they come to gain significantly from the project. By ignoring such groups in favour of an assumption that community interests are homogeneous, development agencies strongly risk their projects being unsustainable.

Another social group receiving a raw deal in this project is women. Among their socially-assigned domestic duties is the collection of fodder and fuelwood. As a consequence of the enclosure of the commons, women's workload has increased - by as much as three hours per day, according to some informants - as they are now forced to travel much further for these products. Women did not participate in the decision to enclose the commons - indeed most, regardless of caste or class, have attended no meetings about the watershed project - yet bear major costs as a result of it. 
While they have participated in the enclosure, this has been passively, in providing cheap labour to construct the boundaries. Nevertheless there has been no major protest from the women, excepting a few instances of quiet resistance where women have 'stolen' branches from field fences at night. While women complain of overwork and fatigue, none have openly questioned the decisions taken by their men folk. This is not surprising as the institutions which subordinate women, and repress their desires, speech, ideas and even emotions, remain very strong in this part of Rajasthan.

In effect, then, in the name of social cohesion the interests of the less powerful are forgone and existing inequalities are reinforced. Policy-makers need to question whether this kind of social cohesion - which reinforces social inequality in society and represses the already oppressed - is really the ideal which they are interested in achieving. They also need to question whether such passive participation realises the aims of participatory watershed development, and to reflect on how more active participation from the less powerful might be fostered.

While drawing attention to institutional dynamics and power politics at the micro-level, environmental entitlements analysis is also useful in highlighting the interplay between local and more 'macro' institutions. This interplay is crucial for the outcome of any outside intervention. In the three case studies considered in this paper, relevant macro-level institutions included the laws and policies of central and state government regarding land tenure, watershed development and tribal area development (Figure 5). 'Meso' level institutions included the office of the patwari. These interacted with more localised institutions such as the caste system, local authority structures and the gender division of labour. The impact of Seva Mandir, as another meso-level institution, was shaped by its interaction with these existing institutional dynamics, which were, in turn, influenced through interaction with the project.

Figure 5 Institutional analysis matrix

\section{Conclusions}

It is imperative that the 'community' should not be considered passive recipients but should be acknowledged as people with diverse interests and resources who may actively shape the outcome of any institution. Policies therefore be prepared for uncertainties and the unintended outcomes of institutional dynamics.

As the case studies from Nyakheda have shown, natural resource management is inextricably intertwined with local contexts. No simple blueprint can be adopted. Watershed development activities need to be seen in relation to people's capabilities more generally, which may require prior support. There is therefore a need to recognise that any community is heterogeneous and dynamic, with different social actors having different sets of environmental entitlements and endowments and so diverse and sometimes divergent interests in natural resource management projects. More specifically, in the Indian context, changing relationships among occupation groups (sustained by caste) requires close attention. Expecting consensus is unfounded. There 
are always some who lose out. By making people sit on a common platform, one does not necessarily make them equal. An analysis of social differences existing behind any image of community may allow projects to take seriously the claims of the socially excluded and actively negotiate outcomes and alternative livelihood sources for certain social groups

\section{References}

Chopra,K., 1990, 'Participatory development: People and common property resource', Studies in Economic Development and Planning, No 52, New Delhi: Sage

Centre for Science and Environment, 1985, 'The State of Indian Environment: The Second Citizen Report', New Delhi

Deshpande, R.S., and Reddy, V.R., 1991, 'Differential impacts of watershed based technology: Some analytical issues', Indian Journal of Agricultural Economics, Vol 46 No 3: 261-269

Frazer, L.O., 1996, 'India's hope: The defiance in Nayakheda', English Translation of article published in Dagens Nyheter, Sweden's largest morning newspaper of India, 1949, 'A report of the Rajasthan- Madhya Bharat enquiry committee', Delhi

Jodha, N.S., 1989, Fuel and Fodder Management in the Arid Regions of Western

Rajasthan, International Centre For Integrated Mountain Development, Kathmandu, Nepal

Kerr, J.M., 1996, 'Economics of pasture development and protection in Rajasthan', Interim Report (Draft), submitted to Department of Watersheds and Soil Conservation, Government of Rajasthan by International Crops Research Institute for the Semi-Arid Tropics

Mosse, D., 1997, 'The symbolic making of a common property resource: History, ecology and locality in tank-irrigated landscape in South India', Development and Change, Vol 28, No 3

Pretty and Shah, 1996, 'Making soil and water conservation sustainable: From coercion and control to partnerships and participation', in forthcoming Land Degradation and Rehabilitation

Saint, K., 1995, 'Social dynamics of natural resource management', Social Change, Vol 25, No 1

Sanghi, N.K., 1987, 'Participation of farmers as co-research workers: Some case studies in dryland agriculture', Paper presented to IDS Workshop on Farmers and Agricultural Research: Complementary Methods. Institute Of Development Studies, Sussex, U.K

Sharma, K., 1995, 'Macro policies for natural resource management- Marginalisation of poor rural women', Center for Women's Development Studies, Occasional Paper No 14, New Delhi: CWDS

Singh,D., 1964, Land Reforms in Rajasthan: A Study of Evasion, Implementation and the Socio-Economic Effects of Land Reforms, New Delhi: The Planning Commission of India 